\title{
Neuroplasticity Mediated by Altered Gene Expression
}

\author{
Colleen A McClung ${ }^{1}$ and Eric J Nestler ${ }^{\star, 1}$ \\ ${ }^{1}$ Department of Psychiatry and Center for Basic Neuroscience, UT Southwestern Medical Center, Dallas, TX, USA
}

Plasticity in the brain is important for learning and memory, and allows us to respond to changes in the environment. Furthermore, long periods of stress can lead to structural and excitatory changes associated with anxiety and depression that can be reversed by pharmacological treatment. Drugs of abuse can also cause long-lasting changes in reward-related circuits, resulting in addiction. Each of these forms of long-term plasticity in the brain requires changes in gene expression. Upon stimulation, second messenger pathways are activated that lead to an enhancement in transcription factor activity at gene promoters. This stimulation results in the expression of new growth factors, ion channels, structural molecules, and other proteins necessary to alter the neuronal circuit. With repeated stimulation, more permanent modifications to transcription factors and chromatin structure are made that result in either sensitization or desensitization of a circuit. Studies are beginning to uncover the molecular mechanisms that lead to these types of long-term changes in the brain. This review summarizes some of the major transcriptional mechanisms that are thought to underlie neuronal and behavioral plasticity. Neuropsychopharmacology Reviews (2008) 33, 3-17; doi:10.1038/sj.npp.1301544; published online 29 August 2007

Keywords: addiction; depression; transcription; learning and memory

\section{INTRODUCTION}

Neuroplasticity refers to the brain's ability to adapt and change over time. This plasticity underlies all types of memory formation (Barco et al, 2006). These can be memories of places, individuals or events. In addition, plasticity occurs in reward- and stress-related centers of the brain, so that one can remember and seek out reinforcing stimuli that are advantageous to survival and avoid potentially dangerous situations. However, drugs of abuse can hijack these circuits and induce abnormally persistent drug reward-related memories and in the extreme addiction (Hyman et al, 2006-review of the memory forming processes associated with addiction). Likewise, exposure to physical or emotional stresses can lead to depression or other mood or anxiety disorders (Duman, 2002; Nestler et al, 2002). Antidepressants and psychotherapeutic treatments can reverse these stress-related changes, and this is thought to mediate their efficacy. Therefore, long-term plasticity in the brain is highly relevant to both normal learning and memory, and the development and treatment of psychiatric disorders.

Work from diverse fields has suggested that common molecular and cellular mechanisms underlie aspects of all of these types of plasticity, and that long-term plasticity in the

${ }^{*}$ Correspondence: Dr EJ Nestler, Department of Psychiatry, Center for Basic Neuroscience, UT Southwestern Medical Center, 5323 Harry Hines Blvd, Dallas, TX 75390-9070, USA, Tel: +214 648 1111, Fax: + 214648 4947, E-mail: Eric.Nestler@utsouthwestern.edu

Received 23 April 2007; revised 26 June 2007; accepted 22 July 2007 brain requires changes in gene expression. The most wellcharacterized potential cellular mechanisms of plasticity are long-term potentiation (LTP) and long-term depression (LTD) (Malenka and Bear, 2004-a review of what is known about the regulation of LTP and LTD and the role of these events in memory formation). LTP and LTD describe longlasting changes in the efficiency of synaptic transmission that occur in response to repeated stimulation. The diverse signal transduction pathways implicated in mediating LTP and LTD in different brain regions have been reviewed recently (Malenka and Bear, 2004). Both LTP and LTD appear to be important in the development of all types of memory formation including the reward-related memories associated with drug addiction (Hyman et al, 2006). The first indication that new gene expression is required for long-term plasticity came from several studies showing that LTP does not persist when animals are injected with protein synthesis inhibitors (Krug et al, 1984; Stanton and Sarvey, 1984 - one of the first studies to show that LTP in the hippocampus is dependent on new gene expression; Montarolo et al, 1988; Otani et al, 1992). These drugs also have severe effects on memory formation, reactivation, and reconsolidation, suggesting that new protein expression is necessary for these processes as well (Davis and Squire, 1984; Rudy et al, 2006). Although it has long been thought that protein synthesis was only needed for the induction of the late phase of LTP or LTD, a recent study by Fonseca et al (2006) shows that early LTP can also be dependent on protein synthesis when there are high levels of synaptic activation, and that the requirement for new protein synthesis can extend well beyond LTP induction, depending 
on the degree of synaptic stimulation. Therefore, the regulation of new gene expression in response to stimulation may be important in most aspects of LTP and LTD.

\section{TRANSCRIPTION FACTORS AND PLASTICITY}

Gene expression is controlled by a series of DNA-binding proteins known as transcription factors. With cellular stimulation, modifications are made to transcription factors that allow nuclear entry, change protein stability, enhance DNA binding, or allow binding to essential co-factors. Several studies have identified specific transcription factors that are important in the persistence of LTP, LTD, and other forms of neural and behavioral plasticity.

\section{A Role for CREB}

The most well-studied transcription factor in the context of neural plasticity is the cAMP response element-binding protein (CREB). CREB binds to the cAMP response element (CRE) in many gene promoters, including several growth factors, enzymes, structural proteins, and other transcription factors (Lonze and Ginty, 2002 - an overview of CREB function and CREB family members and how they regulate various processes). CREB can be modified in multiple ways leading to changes in activity or stability of the protein. For example, it can be phosphorylated at multiple sites, acetylated by CREB-binding protein (CBP), ubiquitinated and targeted for degradation, glycosylated, or stabilized through SUMOylation (Johannessen et al, 2004). CREB can also interact with at least 30 other proteins, all of which affect the ability of CREB to influence gene expression (Johannessen et al, 2004). Upon stimulation, CREB can be activated via phosphorylation at Serine-133 by several signal transduction cascades involving protein kinase A (PKA), $\mathrm{Ca}^{2+} /$ calmodulin (CaM)-kinases, and growth-factor related kinases (eg ribosomal S6 kinase, which is down- stream of extracellular signal-regulated kinases (ERK)) (Figure 1) (Mayr and Montminy, 2001; Lonze and Ginty, 2002). CREB can also be phosphorylated at Ser-142 by CaMKII, which generally leads to a decrease in activity, however, positive effects of this phosphorylation on transcription have been observed as well (Johannessen et al, 2004). In addition, CREB can be phosphorylated at Ser-129 by glycogen synthase kinase $\beta$ (GSK-3 $\beta$ ); the function of this event is still unclear, but it may reduce the activity of CREB at certain gene promoters and enhance activity at others (Salas et al, 2003; Hansen et al, 2004; Johannessen et al, 2004).

Late-phase LTP at cortical synapses leads to an increase in the Ser-133 phosphorylation of CREB (Hotte et al, 2007) and an increase in CREB activity is observed in the hippocampus following training in certain tasks, or memory provoking stimuli (Bito et al, 1996; Taubenfeld et al, 1999). Furthermore, in hippocampal neuronal cultures, activation of NMDA receptors increases Ser-133 CREB phosphorylation, whereas chronic cellular stimulation by bicuculline further increases this NMDA-dependent phosphorylation of CREB (Ehlers, 2003). There is evidence to suggest that multiple signal transduction cascades are required for full activation of CREB. Consequently, CREB-mediated gene expression can be different depending on the strength of the stimulation (Johannessen et al, 2004). In addition, activation of certain signal transduction cascades leads to a prolonged Ser-133 phosphorylation of CREB, producing more long-lasting changes in gene expression, while others produce only a transient phosphorylation (Johannessen et al, 2004). This prolonged Ser-133 phosphorylation of CREB is seen with stimulation of the ERK pathway, one that is required for LTP maintenance and normal memory (Atkins et al, 1998; Schafe et al, 2000; Wu et al, 2001; Deisseroth and Tsien, 2002). Expression of a constitutively active form of CREB (VP16-CREB) in the CA1 region of the hippocampus lowers the threshold for eliciting the persistent late-phase LTP (Barco et al, 2002; Barco et al, 2005),

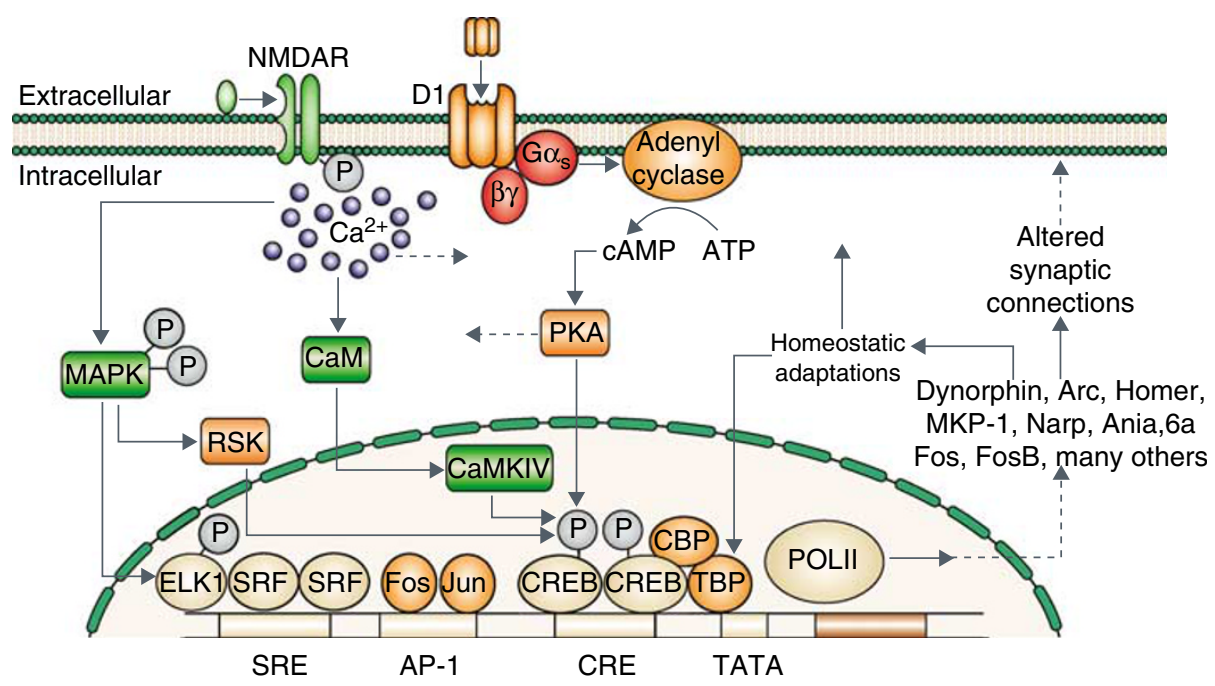

Figure I Regulation of CREB activity. Stimulation of DI dopamine receptors and glutamate receptors on striatal neurons activates several second messenger cascades. Shown in the cell nucleus is a model of binding sites from the CFOS promoter including a serum response element (SRE), activator protein-I element (AP-I), and a cyclic AMP (CAMP) response element (CRE). CBP, CREB-binding protein; CREB, cAMP response element binding protein; MAPK, MAP kinase; NMDAR, NMDA receptor; PKA, protein kinase A; TBP, TATA binding protein. Modified from Hyman et al (2006). 
and promotes NMDA receptor function (Marie et al, 2005). Some of these effects are dependent on the CREB target gene, brain-derived neurotrophic factor (BDNF) (Barco et al, 2005). Moreover, inducible overexpression of CREB in Drosophila enhances long-term memory, and overexpression of CREB in the amygdala of rodents leads to enhanced fear memory (Yin et al, 1995-one of the original studies implicating CREB in the formation of long-term memory; Josselyn et al, 2001; Jasnow et al, 2005). Likewise, genetic disruptions of CREB activity in several animal species leads to severe deficits in learning and memory (Yin and Tully, 1996; Mayford and Kandel, 1999; Josselyn et al, 2004). Therefore, CREB appears to be central in the formation of long-term memory.

CREB activity is also increased in reward-related areas of the brain following acute or chronic treatment with opiate drugs (such as morphine and heroin) or psychostimulants (such as amphetamine and cocaine) (Konradi et al, 1994; Hyman et al, 1995; Shaw-Lutchman et al, 2002; ShawLutchman et al, 2003; Walters et al, 2003; Carlezon et al, 2005; Olson et al, 2005). This induction of CREB activity appears to be involved in regulating reward-related measures associated with addiction. Increasing CREB levels by the use of inducible transgenic mice or viral-mediated gene transfer in the nucleus accumbens (NAc), a crucial brain reward region, decreases the conditioned preference for these drugs, whereas blocking CREB function through expression of a dominant-negative protein has the opposite effect (Carlezon et al, 1998; Barrot et al, 2002; McClung and Nestler, 2003). Studies of constitutive CREB knockdown mice generally support these findings (Walters and Blendy, 2001). Furthermore, induction of CREB increases the excitability of GABAergic NAc neurons, whereas the dominant-negative CREB (mCREB) decreases neuronal excitability (Dong et al, 2006). It is thought that these acute actions of CREB represent a feed-back mechanism in which the increased activation of CREB by drugs of abuse in the NAc induce a decrease in dopaminergic activity, leading to drug tolerance and dependence, as manifested in dysphoria during withdrawal (Figure 2) (Carlezon et al, 2005). Indeed, one of the target genes of CREB, prodynorphin, encodes a peptide (dynorphin) that is released from NAc neuron projections in the ventral tegmental area (VTA) where it binds to $\kappa$ opioid receptors on dopaminergic neurons and decreases dopamine release (Cole et al, 1995). A recent study by found that inhibition of CREB expression by antisense oligonucleotides in the NAc selectively reduced cocaine self-administration and increased the threshold dose of cocaine needed to reinstate self-administration after a period of withdrawal. These findings suggest that activation of CREB in the NAc, and the downregulation of reward mechanisms, can lead to increased drug selfadministration and relapse, perhaps as a result of the associated dysphoria.

CREB activity in other brain regions is also involved in plasticity associated with drug addiction. The actions of CREB in the VTA are complex, in that CREB overexpression in the rostral $v s$ caudal subregions of the VTA have opposing effects on opiate and psychostimulant preference (Walters et al, 2003; Olson et al, 2005). This may be due to differences in the proportion of dopaminergic and GABAergic neurons in these two subregions. CREB in the VTA is also implicated in nicotine reward (Walters et al, 2005 - an important study that outlines a crucial role for CREB in the ventral tegmental area in nicotine reward). In addition to the VTA, CREB may modulate drug reward through its actions in the lateral hypothalamus (LH). CREB activity is induced in this area following chronic opiate or psychostimulant treatment (Shaw-Lutchman et al, 2002; Georgescu et al, 2003; Shaw-Lutchman et al, 2003; Georgescu et al, 2005), and CREB overexpression in the $\mathrm{LH}$ increases the conditioned preference for morphine,

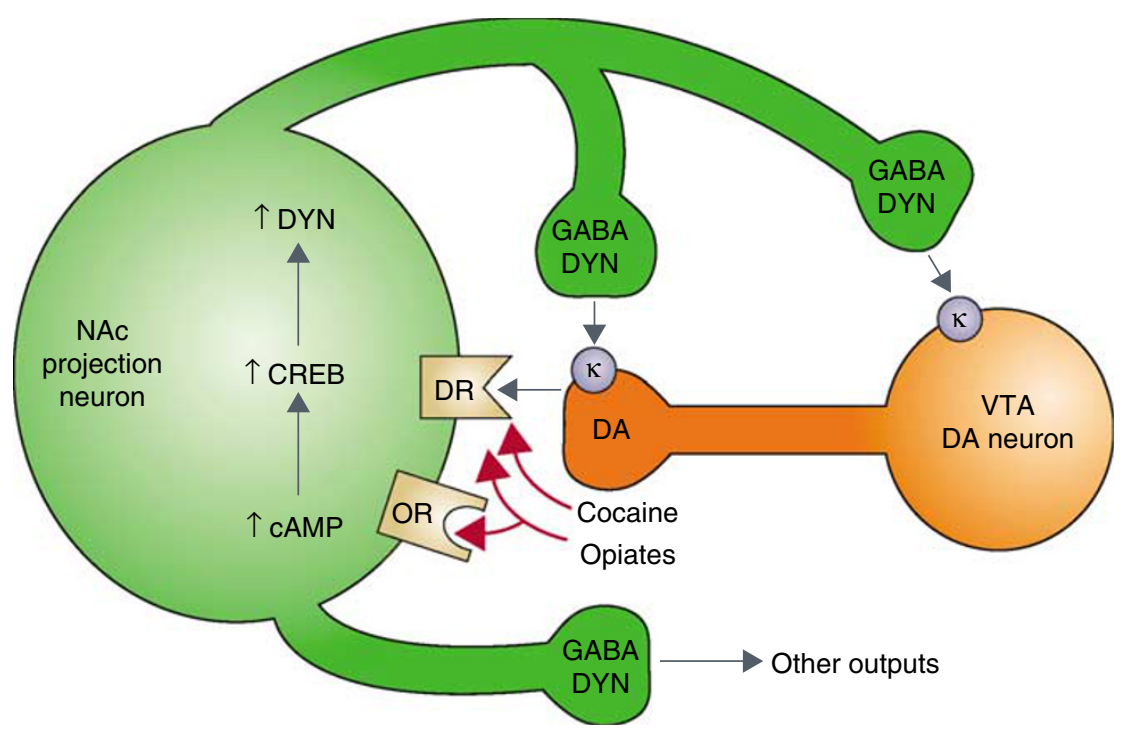

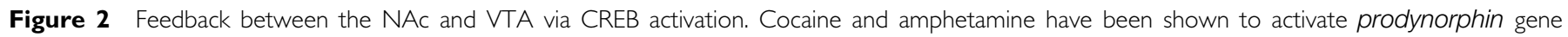

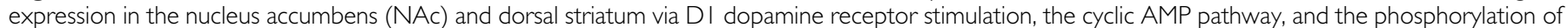

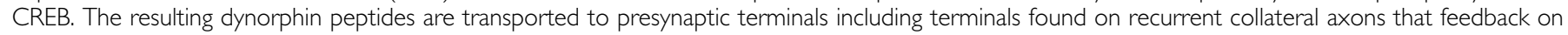

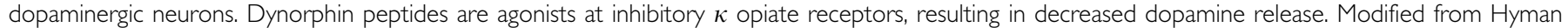
et al (2006). 
whereas expression of a dominant-negative CREB decreases morphine preference (Olson et al, 2007). Together, these results show that CREB is involved in regulating druginduced plasticity in multiple brain regions.

CREB also appears to be involved in the development and treatment of mood and anxiety disorders. However, studies showing the effects of stress on CREB activity are highly dependent on the method and duration of stress and brain region examined. For example, CREB activity is increased in the NAc following stress associated with short-term foot shock, restraint, and unfamiliar social interactions, whereas long-term social isolation decreases CREB activity in the NAc (Barrot et al, 2002; Barrot et al, 2005). Chronic, unpredictable stress also decreases Ser-133 CREB phosphorylation in the dentate gyrus of the hippocampus and the frontal cortex (Gronli et al, 2006; Xu et al, 2006). However, restraint stress increases CREB activity in the frontal cortex with no effects on the hippocampus (Miller et al, 2006).

Induction of CREB causes very different functional effects - either antidepressant-like or pro-depression-like effects - depending on the brain region involved (Duman, 2002; Blendy, 2006; Nestler and Carlezon, 2006). Selective overexpression of CREB in the dentate gyrus of the hippocampus has an antidepressant effect in multiple behavioral measures (Chen et al, 2001a). In contrast, overexpression of CREB in the amygdala or NAc has a prodepressant effect, whereas dominant-negative CREB (mCREB) expression results in an antidepressant-like response in several behavioral measures (Pliakas et al, 2001; Newton et al, 2002; Wallace et al, 2004). These results highlight the importance of CREB in this type of plasticity, and how the changes evoked from these types of stimuli differ throughout the brain.

Other CREB family members act as modulators of CREmediated transcription and contribute to the regulation of neuronal plasticity. The actions of CREB can be inhibited by the inducible cAMP early repressor (ICER) proteins, which are protein products of the CRE modulator gene (Crem) (Mioduszewska et al, 2003). Although overexpression of CREB in the hippocampus of older rats (15 months old) leads to an improvement in long-term memory over wildtype animals, overexpression of an ICER protein decreases long-term memory in spatial-navigation and passive avoidance tasks (Mouravlev et al, 2006). Furthermore, reported recently that acute exposure to either stress or psychostimulants induces ICER proteins in the NAc, and overexpression of an ICER protein in this region through viral-mediated gene transfer, like overexpression of the artificial dominant-negative $\mathrm{mCREB}$, enhances responses to drugs of abuse and natural rewards, and induces an antidepressant-like effect. These results suggest that natural inhibitors of CREB are involved in modulating neural plasticity relevant to drug addiction and stress-related disorders.

\section{A Role for $\Delta$ FosB}

The Fos family of transcription factors, including cFos, FosB, $\Delta$ FosB, Fos-related antigen 1 (Fra1), and Fra2, dimerize with Jun proteins to form an AP-1 transcription factor complex (Hess et al, 2004). LTP stimulation in the dentate gyrus leads to an increase in AP-1 DNA binding, $4 \mathrm{~h}$ after stimulation, suggesting that this enhanced binding is associated with late-phase LTP and long-term plasticity (Williams et al, 2000). All Fos family proteins are induced rapidly in many brain regions following various types of acute stimulation. With more chronic treatments, this induction becomes less and less prominent. However, $\triangle$ FosB, a splice variant of the Fos $B$ gene, is an unusually stable protein that accumulates with chronic treatments (McClung et al, 2004-a recent review of the actions and regulation of DeltaFosB). As this protein is so persistent, it is thought that it is important in the induction and maintenance of long-term plasticity. Indeed, $\triangle \mathrm{Fos} B$ is induced by a wide range of chronic stimuli, including repeated exposure to many types of drugs of abuse or stress, in specific brain regions (McClung et al, 2004; Perrotti et al, 2004). $\Delta$ FosB also appears to have different functions over time, in that, it acts much like a transcriptional repressor at AP-1 sites with short-term treatments, but then functions as a transcriptional activator, as it accumulates with more chronic treatments (McClung and Nestler, 2003).

When the FosB gene is knocked out, resulting in the absence of both FosB and $\Delta$ FosB, mice have behavioral abnormalities in response to drugs of abuse, and in measures of anxiety and depression, that are more pronounced when mice are stressed, suggesting that this gene is important in the regulation of these responses ( $\mathrm{Zhu}$ et al, 2007). Long-term overexpression specifically of $\Delta$ FosB in the NAc mimics an overall addiction-like phenotype seen in response to drugs of abuse (Kelz et al, 1999; Colby et al, 2003; Zachariou et al, 2006). Conversely, the expression of a dominant-negative c-Jun, termed $\Delta \mathrm{c}$-Jun, which acts as a repressor of AP-1 activity, in NAc opposes this addictionlike phenotype (Peakman et al, 2003; Zachariou et al, 2006). Long-term $\triangle \mathrm{FosB}$ expression in the NAc also leads to enhanced food-reinforced instrumental performance and an increase in voluntary wheel running, suggesting that it is important in the response to natural as well as drug rewards (Werme et al, 2002; Olausson et al, 2006). Recently, found that $\Delta$ FosB is phosphorylated by casein kinase 2 (CK2) at Serine 27, and that this phosphorylation opposes protein degradation, contributing to $\Delta$ FosB's unusual stability. Furthermore, this phosphorylation event increases the transcriptional activity of $\Delta \mathrm{FosB}$ (Ulery and Nestler, 2007). As it has been shown that LTP induction rapidly increases the activity of CK2 in the hippocampus (Charriaut-Marlangue et al, 1991), it is possible that this provides a mechanism by which the activity of $\Delta$ FosB is increased and stabilized following chronic stimulation, leading to some of the long-term gene expression changes responsible for plasticity. $\Delta$ FosB's unusual stability is also due to the fact that it lacks two degron domains present in the Cterminus of full-length FosB and all other Fos family proteins, which target these proteins for rapid degradation (Carle et al, 2007).

\section{A Role for NF- $\kappa \mathrm{B}$}

The transcription factor, NF- $\kappa \mathrm{B}$, can exist as a latent form or a constitutively active form in neurons (Kaltschmidt et al, 2005). Although the constitutive form is located in the nucleus, the latent form is held in the cytoplasm through an 
interaction with inhibitory kappaB $(\mathrm{I} \kappa \mathrm{B})$. Upon stimulation by numerous factors, $\mathrm{I} \kappa \mathrm{B}$ is degraded, allowing NF- $\kappa \mathrm{B}$ to enter the nucleus. In addition, the RelA subunit of NF- $\kappa \mathrm{B}$ can be acetylated upon stimulation and this prevents its interaction with $\mathrm{I} \kappa \mathrm{B} \alpha$ (Chen et al, 2001b). RelA can subsequently be deacetylated by histone deacetylase 3 (HDAC3), and this promotes nuclear export and $\mathrm{I} \kappa \mathrm{B} \alpha$ binding (Chen et al, 2001b). This reversible acetylation contributes to the duration of NF- $\kappa \mathrm{B}$ activity in the nucleus. $\mathrm{NF}-\kappa \mathrm{B}$ is activated in response to neurodegeneration, cellular stress, or trauma, and through its regulation of antiapoptotic genes, it promotes neuronal survival (Mattson, 2005). NF- $\kappa$ B activity is also induced following LTP in the hippocampus and after fear conditioning in the amygdala (Yeh et al, 2002; Romano et al, 2006). Studies have found that the administration of a competing decoy $\kappa \mathrm{B}$ can prevent LTD and severely impair LTP in both the hippocampus and amygdala (Albensi and Mattson, 2000; Yeh et al, 2002). In addition, members of the NF- $\kappa \mathrm{B}$ family, p50, p65, and c-Rel, show an increase in DNA binding in the hippocampus following glutamate receptor stimulation, and mice lacking c-Rel have a deficit specifically in the latephase of LTD (O'Riordan et al, 2006). Furthermore, animals that overexpress a 'super repressor' $\mathrm{I} \kappa \mathrm{B}-\mathrm{AA}$ in neurons selectively using a bitransgenic system have defects in learning and memory (Kaltschmidt et al, 2006). The late phase of hippocampal LTP in these mice is also compromised and LTD can not be induced (Kaltschmidt et al, 2006). Interestingly, this study identified the PKA catalytic $\alpha$-subunit as a transcriptional target for NF- $\kappa \mathrm{B}$, and the loss of NF- $\kappa \mathrm{B}$ function reduces PKA-mediated CREB phosphorylation (Kaltschmidt et al, 2006). Thus, the plasticity and memory defects in the $\mathrm{I} \kappa \mathrm{B}-\mathrm{AA}$ overexpressing mice may come from a lack of activated CREB.

In addition to the effects on memory, NF- $\kappa \mathrm{B}$ is also induced by chronic cocaine in the NAc, where it may be a transcriptional target of $\Delta$ FosB (Ang et al, 2001). Therefore, $\mathrm{NF}-\kappa \mathrm{B}$ may also be involved in the plasticity associated with addiction, a possibility, which now requires further investigation.

\section{A Role for Circadian Transcription Factors}

Recent studies have implicated the transcription factors that make up the circadian clock in neural plasticity. Circadian rhythms, or 24-h cycles, occur in many bodily functions, including sleep/wake, body temperature, and hormone levels. Circadian rhythms are largely regulated by a transcriptional feed-back loop located in the suprachiasmatic nucleus (SCN) in the hypothalamus. However, the genes that make up the clock are expressed throughout the brain and other organs, and can form SCN-independent oscillators that respond to many types of external stimuli (King and Takahashi, 2000 - a review of the circadian clock and rhythms in mammals; Abe et al, 2001; Reppert and Weaver, 2001; Stokkan et al, 2001; Iijima et al, 2002; Granados-Fuentes et al, 2006; McDearmon et al, 2006; Mieda et al, 2006). In fact, it is estimated that $>10 \%$ of all mammalian messenger RNA (mRNA) transcripts are regulated in a circadian manner (Akhtar et al, 2002; Duffield et al, 2002).
The major transcriptional activator consists of a dimer between the Circadian Locomotor Output Cycles Kaput Protein (CLOCK) and Brain and Muscle ARNT-like Protein 1 (BMAL1, also known as ARNTL or MOP3). This complex binds to E-box sequences in the promoters of many genes, including the Period (Per) and Cryptochrome (Cry) genes. The PER and CRY proteins are translated in the cytoplasm, and are phosphorylated by casein kinase I $\varepsilon$ and $\delta$ (CK1) and GSK $3 \beta$, leading to changes in their stability, association, and nuclear entry (Harms et al, 2003; Iitaka et al, 2005; Knippschild et al, 2005; Kurabayashi et al, 2006). These proteins can then repress the actions of CLOCK:BMAL1, which creates a precisely timed transcriptional feedback loop, the molecular basis of circadian rhythms. In addition, there is an adjoining loop in which CLOCK:BMAL1 activates the transcription of Rev-erb $\alpha$ and Ror $\alpha$ (Sato et al, 2004; Guillaumond et al, 2005). These proteins can bind to the promoter of the Bmal1 gene and both positively and negatively regulate its transcription. Selectively in forebrain regions, Neuronal PAS Domain Protein 2 (NPAS2), a protein very similar to CLOCK, can bind BMAL1 and induce Per and Cry gene expression independent of CLOCK (Reick et al, 2001). NPAS2 may also function in the place of CLOCK in the SCN, if the CLOCK protein is abolished (Debruyne et al, 2006).

It is thought that sleep contributes strongly to the process of memory formation and consolidation (Walker and Stickgold, 2006). In addition, phase shifting of circadian rhythms or chronic disruption of circadian rhythms can impair long-term memory and working memory in both rodents and humans (Cho et al, 2000; Devan et al, 2001). Several studies have found differences in learning and memory when experiments are performed during the light cycle $v s$ the dark cycle. For example, snails display a diurnal regulation of conditioned taste aversion (Wagatsuma et al, 2004). Rodents also show diurnal differences in contextual fear conditioning and performance in the Morris water maze (Chaudhury and Colwell, 2002; Valentinuzzi et al, 2004). In addition, the magnitude of hippocampal LTP is greater and the decay of LTP is slower during the night in nocturnal mice, even when the mice are kept in constant darkness, suggesting that an endogenous circadian oscillator regulates hippocampal plasticity (Chaudhury et al, 2005). Studies in Aplysia found that long-term memory formation in response to electrical stimulation or 5-HT is suppressed in diurnal animals that were trained during the night (Fernandez et al, 2003; Lyons et al, 2005, 2006). This reduction in memory formation during the night was correlated with a circadian rhythm in the induction of the memory-related proteins, phosphorylated ERK, and CCAAT/enhancer-binding protein, such that a greater induction of these proteins was seen when training was performed during the day than at night (Lyons et al, 2006). Long-term memory formation at night could be restored to day-time levels when animals were treated with agents that activate ERK and another transcriptional activator together, but not individually, indicating that both ERK phosphorylation and general gene transcription are necessary for normal memory formation, and that both are inhibited by the circadian clock during the night.

Additional studies have implicated individual members of the circadian clock or clock-controlled hormones in 
learning and memory. Drosophila that carry a mutation in the Per gene are defective in long-term memory associated with experience-dependent courtship, whereas overexpression of Per enhanced memory formation in this paradigm (Sakai et al, 2004). Interestingly, mutations in other circadian genes including Clock and Cycle did not affect memory formation in this task, suggesting an independent role for Per outside of the central clock (Sakai et al, 2004). Somewhat surprisingly, mice that lack functional Per1 or Per2 show normal spatial and contextual learning in hippocampal-dependent tasks (Zueger et al, 2006), however, mice lacking both genes have not been tested. The circadian hormone, melatonin, which is released at night in response to signals from the SCN, can inhibit hippocampal LTP (Wang et al, 2005). As well, expression of the circadiancontrolled transcription factor, albumin D-element-binding protein (DBP), is suppressed by hippocampal activation of a protein associated with increased learning, glucagon-like peptide-1 receptor, and viral-mediated overexpression of DBP in the hippocampus leads to an inhibition of spatial learning (Klugmann et al, 2006). Moreover, induction of LTP leads to the phosphorylation and inhibition of the circadian modulator, GSK-3 $\beta$ in the hippocampus (Hooper et al, 2007) LTP is impaired in mice that conditionally overexpress GSK-3 $\beta$ and the deficits can be rescued by treatment with the GSK-3 $\beta$ inhibitor, lithium (Hooper et al, 2007). These results suggest that certain components of the molecular clock are involved in learning and memory.

Several mood and substance abuse disorders have also been strongly linked to the circadian clock (Bunney and Bunney, 2000; Mansour et al, 2005; Yuferov et al, 2005; Wirz-Justice, 2006). Indeed, some of the most pronounced symptoms of diseases like major depressive disorder (MDD) and bipolar disorder (BPD) are abnormal sleep/wake, appetite, and social rhythms (Boivin, 2000; Bunney and Bunney, 2000; Lenox et al, 2002; Grandin et al, 2006). In addition, nearly all of the successful treatments for mood disorders affect circadian rhythms, and it appears that the shifts, resetting, and stabilization of these rhythms, produced by these treatments, are important for their therapeutic efficacy (McClung, 2007). Interestingly, a recent study found that the circadian genes, Clock, Npas2, and Bmal1, are all strongly induced in the mouse hippocampus after chronic, but not acute, treatment with the antidepressant, fluoxetine (Uz et al, 2005). This suggests that these genes may be involved in the plasticity that occurs in this region with chronic antidepressant treatment. In addition, chronic treatment with the mood stabilizer, valproate, decreased the expression of $C K 1 \delta$ and Cry 2 in the amygdala (Ogden et al, 2004). These changes did not occur when mice were co-treated with methamphetamine, which was given to induce manic-like symptoms, suggesting that these genes may be involved in the treatment of mania (Ogden et al, 2004).

Researchers have begun to examine the roles of individual members of the circadian clock in the regulation of mood and drug addiction. Transgenic mice that overexpress GSK$3 \beta$ are hyperactive, have reduced immobility in the forced swim test (interpreted as lower depression-like behavior), and an increased startle response (Prickaerts et al, 2006). These behaviors are reminiscent of those of bipolar patients in the manic state. This is perhaps not surprising, as
GSK-3 $\beta$ is inhibited by the mood stabilizer, lithium (Jope and Roh, 2006). Recently, Roybal et al (2007) - the authors report a mania-like phenotype, and its reversal by chronic lithium treatment, in mice lacking functional Clock protein - found that mice harboring a mutation in the Clock gene also display a behavioral profile that is strikingly similar to human mania. These mice have a point mutation in the Clock gene that results in the expression of a dominant-negative protein (King et al, 1997). These mice are extremely hyperactive in response to novelty and throughout the light/dark cycle, they have reduced depression-like behavior in the forced swim and learned helplessness tests, reduced anxiety or increased risk-taking behavior in several measures, and an increase in the reward value of cocaine, sucrose, and intracranial self-stimulation (McClung et al, 2005; Roybal et al, 2007). In addition, other groups have found that these mice sleep less and have increased exploratory activity, adding to their overall manic-like phenotype (Naylor et al, 2000; Easton et al, 2003). Interestingly, when these mice were treated chronically with lithium, the majority of their behavioral responses return to wild-type levels (Roybal et al, 2007). As the midbrain dopaminergic system has been widely implicated in the development of mania, we performed in vivo recordings from the dopaminergic neurons of the VTA in the Clock mutant mice, and found an overall increase in dopamine cell firing and bursting (McClung et al, 2005; Nestler, 2005; Nestler and Carlezon, 2006). CLOCK is expressed in the VTA, where it regulates several genes that are important in dopaminergic transmission (McClung et $a l, 2005)$. Therefore, we used viral-mediated gene transfer to express a functional CLOCK protein specifically in the VTA of the mutant mice, and found that this treatment returned several of their behavioral phenotypes to wild-type levels (Roybal et al, 2007). These results suggest that CLOCK is important in the development of mania, and that at least a portion of the behavioral and mood-related phenotypes seen in the mutant mice are due to the loss of CLOCK function in the VTA.

As mentioned above, one of the phenotypes of the Clock mutant mice is an increase in the reward value for cocaine. This was measured both by conditioned place preference and by levels of intracranial self-stimulation following cocaine treatment (McClung et al, 2005; Roybal et al, 2007). Other members of the circadian clock have also been implicated in drug reward and addiction. The original studies implicating circadian genes in drug-induced plasticity found that Drosophila lacking Per, Clock, Cycle, or Doubletime all fail to sensitize to cocaine (Andretic et al, 1999 - this is the first study to demonstrate a role for the genes that control circadian rhythms in the regulation of cocaine responsiveness). Since then, several studies have found changes in the expression of multiple circadian genes in various brain regions of rodents treated with drugs of abuse (Nikaido et al, 2001; Ammon et al, 2003; Yuferov et al, 2003, 2005; McClung et al, 2005; Uz et al, 2005; Manev and Uz, 2006). In addition, mice that lack a functional Per1 gene show reduced behavioral responses to cocaine (Abarca et al, 2002). Reduction in the expression of Per1 by DNAzyme targeting likewise leads to a reduction in the conditioned preference for morphine (Liu et al, 2005). However, mice lacking Per1 show normal levels of alcohol 
self-administration and reinstatement of alcohol-seeking behavior, suggesting that Per1 is perhaps not involved in alcohol reinforcement (Zghoul et al, 2007). Interestingly, mice lacking Per2 show an enhanced sensitization to cocaine, but normal levels of conditioned preference for cocaine (Abarca et al, 2002). They also show an increase in alcohol self-administration and enhanced incentive motivation for alcohol (Spanagel et al, 2005). These results suggest that Per1 and Per2 may serve different functions in response to treatment with drugs of abuse.

\section{CHROMATIN MODIFICATIONS THAT UNDERLIE PLASTICITY}

\section{Modifications to Histones}

Long-term modifications to chromatin may underlie some of the changes in gene expression that lead to neural plasticity. DNA is tightly packed around octamers of the histone proteins $\mathrm{H} 2 \mathrm{~A}, \mathrm{H} 2 \mathrm{~B}, \mathrm{H} 3$, and $\mathrm{H} 4$, linked together by histone H1 (Berger, 2001). Histone proteins can be modified to allow the DNA to unwind and permit transcription factor binding and gene activation (Figure 3). In turn, other modifications to histone proteins can inhibit transcription factor binding. Several studies have found that gene activation is associated with histone acetylation (Cheung et al, 2000). This acetylation is catalyzed by a histone acetyltransferase (HAT) enzyme, such as CBP/p300 or many others, which serve as transcriptional co-activators. In addition, some transcription factors appear to have their own HAT domain that may allow histone acetylation. For example, the CLOCK protein has recently been shown to contain an active HAT domain that is enhanced by BMAL1 binding (Doi et al, 2006). HDAC proteins reduce gene expression at these promoters through histone deacetylation. Histone phosphorylation is also generally associated with an increase in transcription, and phosphorylation has been associated with immediate early gene activation in response to growth factor treatment (Mahadevan et al, 1991; Sassone-Corsi et al, 1999).

Histones $\mathrm{H} 3$ and $\mathrm{H} 4$ can also be methylated at arginine or lysine residues, which can lead to gene activation or repression depending on the residue undergoing methylation (Beaujean, 2002). The arginine methyltransferase, co-activator-associated arginine methyltransferase-1, can co-activate myogenic transcription factor-mediated gene expression (Chen et al, 2002). However, methylation of histone $\mathrm{H} 3$ on lysine residues $\mathrm{K} 9$ or $\mathrm{K} 27$ is associated with stretches of transcriptional repression and inert heterochromatin (Beaujean, 2002). Finally, ubiquitination, SUMOylation, and ADP-ribosylation of histones have been observed, and these processes influence gene transcription as well (Huletsky et al, 1985; Davie and Murphy, 1990; Beaujean, 2002; Nathan et al, 2003).

HAT and HDAC proteins can associate with transcription factors, and this association often occurs in response to second messenger stimulation. For example, CREB binds CBP after phosphorylation at Ser-133 (Johannessen et al, 2004). Mice that lack full CBP function through various genetic methods have defects in late-phase LTP, spatial learning, and fear conditioning (Alarcon et al, 2004; Korzus et al, 2004; Wood et al, 2005). Furthermore, studies have found that the induction of LTP in hippocampal slices using high-frequency stimulation is enhanced by treatment with the nonspecific HDAC inhibitors, trichostatin A and sodium butyrate (Levenson et al, 2004). Trichostatin A also enhanced forskolin-induced LTP in the amygdala (Yeh et al, 2004). These results suggest that HDAC inhibition and transcriptional activation may improve the plasticity associated with memory formation.

Long-term modifications to histone proteins have been seen in response to chronic stimuli, where they contribute to neuronal plasticity. Early studies in Aplysia found that acetylation of histone $\mathrm{H} 4$ at the ApC/EBP promoter was increased following 5-HT-induced long-term facilitation,

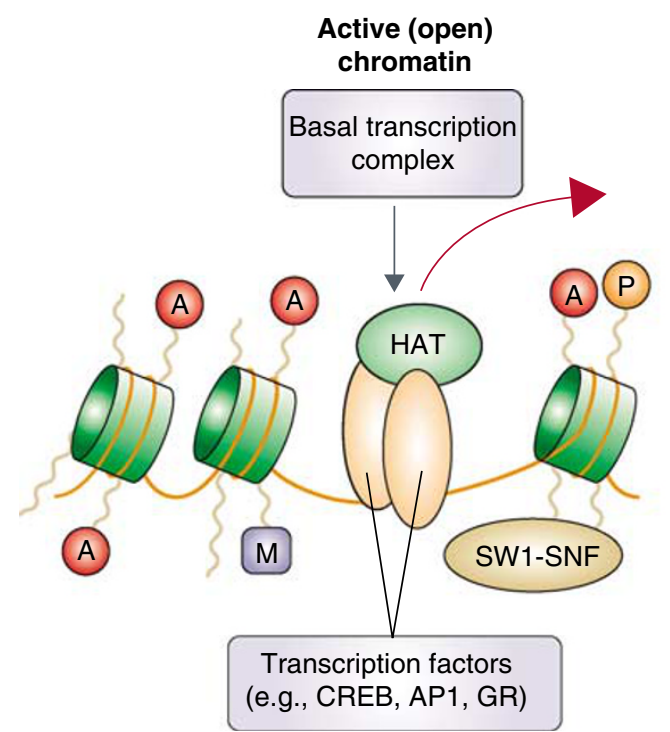

Inactive (condensed) chromatin

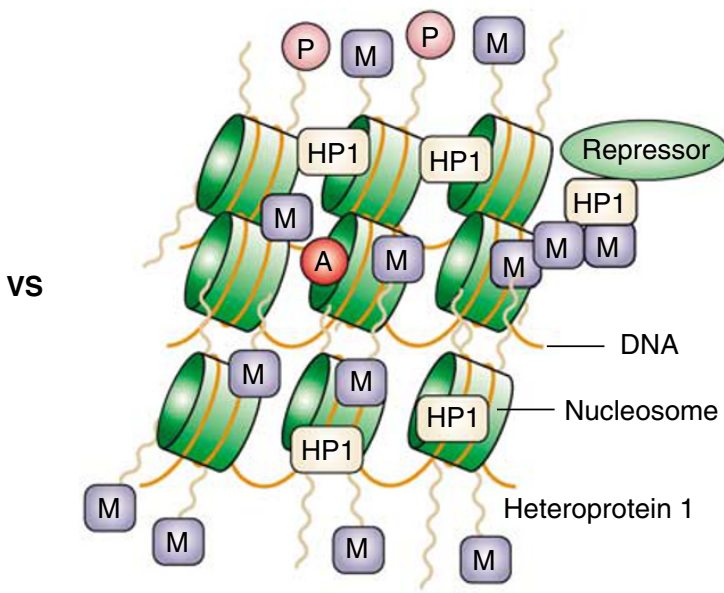

Figure 3 Differential states of chromatin. Chromatin can either be open (ie active, allowing gene expression) or condensed (ie inactive, repressing gene expression). This change in state is mediated by the modifications to core histone proteins. Histone acetylation (A) is associated with chromatin relaxation and the binding of transcription factors and co-activators, such as HATs (histone acetyl transferases) and SWI-SNF proteins that mediate the movement of nucleosomes along a strand of DNA. Histone methylation (M) results in condensed chromatin and transcriptional repression (REP). 
and acetylation was decreased following FMRFamideinduced LTD through the recruitment of HDAC5 (Guan et al, 2002). Later, it was found that multiple signaling pathways modify histones in the rodent hippocampus, including an increase in $\mathrm{H} 3$ acetylation following the activation of NMDA receptors and the ERK pathways associated with LTP (Crosio et al, 2003 - an important paper that delineates some of the intracellular messenger pathways that lead to regulation of histone acetylation; Levenson et al, 2004). In studies of depression, the HDAC inhibitor, sodium butyrate, has an antidepressant-like effect in mice that correlates with hyperacetylation at the $B d n f$ promoter in the frontal cortex (Schroeder et al, 2006; Tsankova et al, 2006 - this is the first study to implicate histone modifications in depression- and antidepressantlike behavior). In agreement with these findings, our studies found that a chronic electroconvulsive seizure paradigm, which is antidepressant in humans, changes the acetylation of specific histones at the $B d n f, C r e b$, and $c$-Fos promoters in the hippocampus, and these changes correlate with sustained increases or decreases in levels of expression of these genes (Tsankova et al, 2004). Furthermore, a chronic social defeat stress paradigm, which produces a depressionlike state (Berton et al, 2006), decreases the expression of $B d n f$ in the hippocampus (Tsankova et al, 2006). The prolonged reduction in $B d n f$ expression was correlated with an increase in repressive histone methylation at the gene promoter (Tsankova et al, 2006). The antidepressant, imipramine reversed the depression-associated behavior and increased histone acetylation at the $B d n f$ promoter and increased $B d n f$ expression (Tsankova et al, 2006). Furthermore, this increase in histone acetylation with imipramine treatment involves the downregulation of HDAC5, and overexpression of HDAC5 in the hippocampus blocks the ability of imipramine to reverse the depression-like behavior (Tsankova et al, 2006). Together, these studies highlight the importance of long-term histone modifications in the plasticity associated with depression and antidepressant treatment.

Chromatin remodeling through histone modification also appears to play a role in drug addiction. One of the key features of addiction is that it is more persistent if drug use begins at an early age, indicating long-lasting changes in brain function. Interestingly, a recent study found that the administration of ascending doses of cocaine to adolescent rats resulted in an increased response to cocaine in adulthood, and an overall decrease in histone $\mathrm{H} 3$ methylation at lysines 4 and 27 in the medial pre-frontal cortex (Black et al, 2006). Furthermore, acute cocaine leads to a transient increase in histone acetylation at the c-Fos promoter in striatal regions, consistent with its transient increase in expression following this treatment (Kumar et al, 2005). However, chronic cocaine treatment selectively increases $B d n f$ and $C d k 5$ gene expression in these regions, and these increases are associated with hyperacetylation at their promoters (Kumar et al, 2005). Kumar et al provided several lines of evidence indicating that induction of the $C d k 5$ gene is mediated via $\triangle$ FosB. Cocaine also increases $\mathrm{CBP}$-mediated acetylation of histone $\mathrm{H} 4$ at the Fos $B$ promoter, and mice lacking one allele of CBP have less accumulation of $\triangle \mathrm{FosB}$, and are less sensitive to chronic cocaine (Levine et al, 2005). Furthermore, administration of the HDAC inhibitor, TSA, increases the conditioned place preference for cocaine, whereas viral-mediated overexpression of HDAC4 in the NAc decreases cocaine preference (Kumar et al, 2005). These results suggest that chronic cocaine treatment leads to a hyperacetylation at several gene promoters, which increases the reward value for cocaine.

\section{DNA Methylation}

DNA (cytosine-5) methylation occurs at methyl CpG islands within a gene sequence, and it was once thought to be a permanent way by which certain genes are silenced. This silencing occurs during $\mathrm{X}$-chromosome inactivation, and several cell-fate determination processes throughout development (Morgan et al, 2005). Recent studies, however, show that changes in DNA methylation may be more transient, and underlie certain types of long-term plasticity. For example, DNA methylation can occur in response to stimuli experienced during development or early childhood, and this can lead to lasting changes into adulthood. A recent study by Weaver et al (2004) - one of the first studies to show that DNA methylation patterns can be influenced during adolescence and that these patterns affect adult behavior - found that patterns of DNA methylation in the glucocorticoid receptor gene were determined during early life based on the quality of maternal care experienced. These patterns or 'memories' remained until adulthood, and influenced levels of anxiety and nurturing behavior in the rats as adults. These results suggest that the methylation patterns that occur during early childhood result in longlasting changes in gene expression that affect adult behavior. Interestingly, these changes in adult behavior were reversible. Infusion of adult rats with the amino-acid L-methionine, a precursor to $S$-adenosyl-methionine that acts as the donor of methyl groups for DNA methylation, reverses the effect of maternal behavior on DNA methylation and the behavioral response to stress (Weaver et al, 2005). This shows that the DNA methylation changes that occur during adolescence are not permanent. Another study, by Zhang et al (2007) found that maternal cocaine use induces persistent DNA methylation of the $P k c \varepsilon$ gene in the heart of the fetus. It is possible that similar changes could occur in the brain, leading to a propensity for drug addiction later in life.

Studies aimed at determining whether or not DNA methylation is involved in more short-term learning and memory are just beginning. Interestingly, a protein that binds methylated cytosines and represses transcription, $\mathrm{MeCP} 2$, has been associated with memory formation. Loss of function mutations in this protein cause Rett syndrome, a developmental disorder that severely affects cognitive and motor abilities (Williamson and Christodoulou, 2006). These behavioral abnormalities are associated with impairments in presynaptic release of glutamate (Nelson et al, 2006 - an important study that demonstrates abnormal presynaptic function in mice lacking MeCP2). Surprisingly, overexpression of MeCP2 enhances hippocampal LTP and long-term memory formation transiently before animals develop seizures, severe hypoactivity, and other ailments (Collins et al, 2004). This suggests that the proper balance of $\mathrm{MeCP} 2$ is needed for memory function. In addition, studies by Chen et al (2003)-one of the first studies to 
demonstrate regulation of the Bdnf gene by DNA methylation mechanisms - and Martinowich et al (2003) found that MeCP2 binds to the $B d n f$ promoter III and inhibits $B d n f$ transcription through $\mathrm{CpG}$ methylation. Membrane depolarization leads to a calcium-dependent phosphorylation of $\mathrm{MeCP} 2$ that dissociates the MeCP2-HDAC-mSin3A complex from the promoter, allowing $B d n f$ transcription (Chen et al, 2003; Martinowich et al, 2003). Furthermore, recent studies by Sweatt and co-workers found that the enzymes that catalyze the methylation of cytosine residues, DNA methyltransferases (DNMTs), are important regulators of memory in the hippocampus (Levenson et al, 2006; Miller and Sweatt, 2007 - a recent study implicating DNA methylation in the formation of long-term memory). Inhibition of DNMT through treatment with phorbol-12,13-diacetate altered the methylation at the reelin and $B d n f$ promoters, and blocked the induction of LTP (Levenson et al, 2006). Furthermore, DNMT expression is upregulated in the hippocampus with contextual fear conditioning, and DNMT inhibition leads to deficits in memory formation (Miller and Sweatt, 2007). DNMT is involved in the silencing of the memory suppressor gene, $P p 1$, and this gene is rapidly inactivated via DNA methylation following fear conditioning (Miller and Sweatt, 2007). These studies suggest that DNA methylation is far more dynamic than previously described and could be an important mechanism that contributes to long-term neuronal plasticity.

\section{POSTTRANSCRIPTIONAL MODIFICATIONS THAT UNDERLIE PLASTICITY}

\section{Polyadenylation Factors}

In addition to the long-term modifications to transcription factors and DNA that govern neuronal plasticity, post- transcriptional mechanisms also appear to be involved. Many mRNAs are transported to synapses where they are locally translated, and participate in synaptic remodeling at those locations. Several studies have identified mRNAbinding proteins, such as the cytoplasmic polyadenylation element-binding protein $(\mathrm{CPEB})$ and cleavage and polyadenylation specificity factor that regulate mRNA translation at the synapse (Wu et al, 1998). Drosophila carrying a mutation in orb, a CPEB homologue, lack long-term memory (Dubnau et al, 2003). Furthermore, NMDA receptor stimulation induces the phosphorylation of CPEB by Aurora kinase, and disrupts its association with a repressor protein, Maskin, thereby allowing CPEB to interact with the translation initiation factors, eIF4G and eIF4E at target mRNAs (Huang et al, 2002; Si et al, 2003-a study showing the importance of postranscriptional regulation by CPEB in plasticity). This action can stabilize synaptic changes at these sites associated with plasticity. Interestingly, the Aplysia CPEB was reported to have prionlike properties in that, it is modular and transferable, and it is capable of conferring a change in state to other proteins (Si et al, 2003). The prion-like, aggregated state is the active state of CPEB, and it is possible that this conformational change comes about through chronic stimulation, leading to long-lasting, local synaptic changes.

\section{MicroRNAs}

Recently, a class of non-coding, micro RNAs (miRNA) has been described that influence the translation of mRNA by sequence-specific pairing with $3^{\prime}$-untranslated regions (Presutti et al, 2006). It is predicted that $40-50 \%$ of mRNAs are regulated by miRNAs (Presutti et al, 2006). A number of these miRNAs appear to be brain specific, and they have been implicated in neuronal development and differentia-

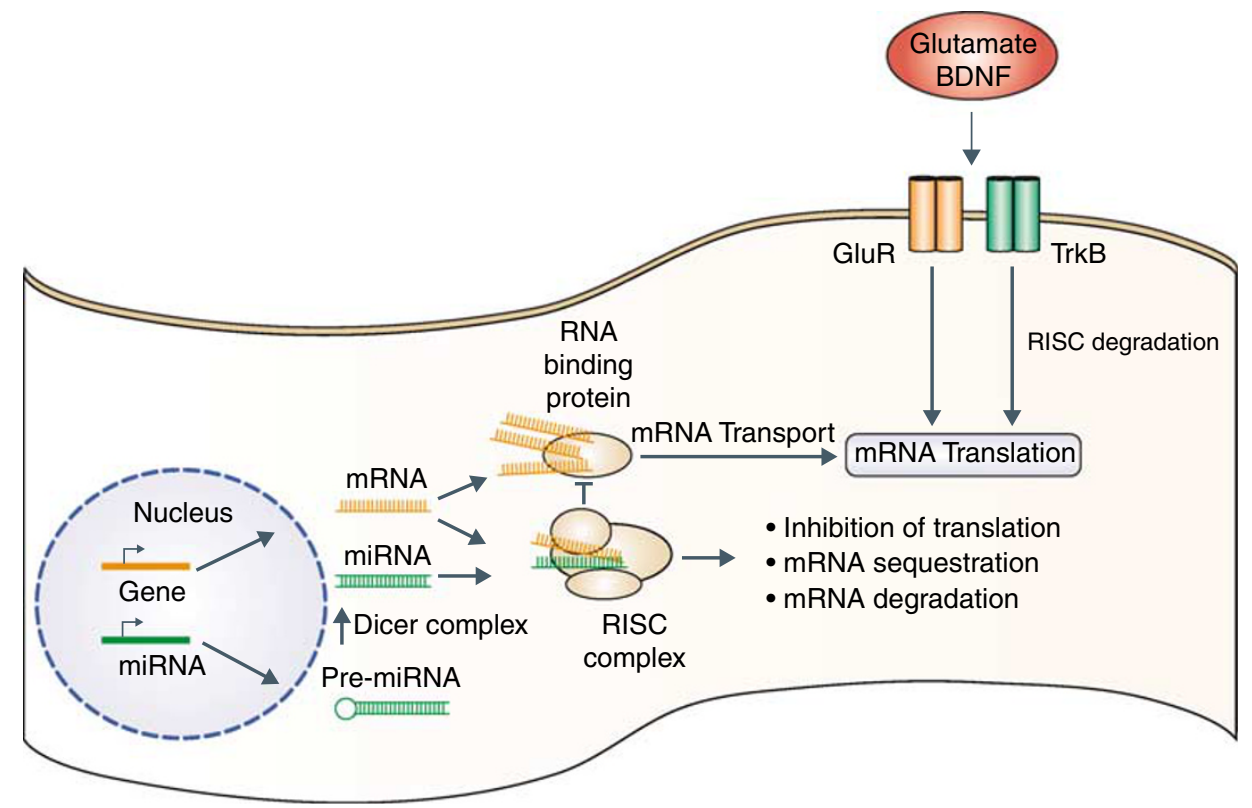

Figure 4 Regulation of mRNA translation by miRNAs. The ability of mRNAs to be locally translated and participate in synaptic plasticity can be altered by miRNAs. This interaction between the miRNA, mRNA, and the RISC complex can lead to the inhibition of translation, mRNA degradation, or the sequestering of the mRNA away from the synapse. Stimulation by glutamate, or growth factors such as BDNF, can lead to the degradation of components of the RISC complex and allow mRNA translation. 
tion (Presutti et al, 2006). These miRNAs also undergo tissue-specific RNA editing, adding another level of potential regulation to their function (Kawahara et al, 2007). It is possible that miRNAs are involved in regulating the local translation of mRNAs at synapses that are involved in plasticity (Figure 4). Many of the structural changes that are thought to underlie synaptic plasticity occur at dendritic spines and branches (Schratt et al, 2006-an important study demonstrating the regulation of dendritic spine growth by a microRNA). miRNAs might be involved in repressing translation of proteins at these synapses under normal conditions, with this repression being abolished following stimulation. Indeed, in the hippocampus, a brainspecific miRNA, miR-134 is localized to the synaptodendritic compartment of neurons where it decreases the size of dendritic spines through its repressive actions at the LIM-domain kinase 1 (Limk1) mRNA (Schratt et al, 2006). Neuronal stimulation by BDNF relieves the repression of Limk1 by miR-134, allowing spine growth (Schratt et al, 2006). Another recent study in Drosophila found that local protein synthesis occurs at synapses when animals are exposed to an odor paired with an electric shock (Ashraf et al, 2006). A component of the RNA-silencing complex (RISC), Armitage, that couples with miRNAs is located at these synapses, where it normally silences mRNAs (Ashraf and Kunes, 2006; Ashraf et al, 2006; Chekanova and Belostotsky, 2006). Upon stimulation, Armitage is degraded, and the mRNA is now translated. Some of the key proteins involved in plasticity are targets of this pathway, including CaMKII and Staufen (Ashraf and Kunes, 2006; Ashraf et al, 2006). Therefore, the RISC complex may play a key role in synaptic plasticity.

Total expression levels of the miRNAs may contribute to the maintenance of long-lasting plasticity. Interestingly, genome-wide screens of transcription factor binding found that CREB may regulate the expression of individual brainspecific miRNAs (33 had identifiable CRE regulatory sequences), and $M i R-132$, a miRNA expressed predominantly in the hippocampus, was identified as a direct target of CREB (Vo et al, 2005; Wu and Xie, 2006; Lukiw, 2007). Furthermore, the transcriptional repressor RE1-silencing transcription factor (also known as neuron-restrictive silencer factor), appears to convey long-term repression of some of the miRNAs by recruiting MeCP2 and HDACs to their regulatory regions ( $\mathrm{Wu}$ and $\mathrm{Xie}, 2006)$. Therefore, long-term treatments could change the expression level of these miRNAs through manipulation of these transcription factors, which would result in more or less local translation of proteins that are involved in altering synaptic connections.

\section{FUTURE RESEARCH DIRECTIONS}

Although it is clear that transcriptional and post-transcriptional changes are necessary for the development of neuroplasticity, the mechanisms that underlie these changes are complex, and we are only beginning to understand how these changes are mediated. In addition, many of the transcriptional target genes that are involved in long-term plasticity have yet to be identified. Therefore, future research into the stimulus-dependent regulation of tran- scription factors, chromatin structure, and mRNA processing are important in our understanding of how long-term changes are facilitated in the brain. The use of new technologies such as chromatin immunoprecipitation (ChIP) followed by microarray analysis (ie ChIP on chip) or DNA methylation arrays will allow us to study chromatin modifications that occur following various treatments, and identify a range of direct transcriptional targets of many transcription factors involved in plasticity. In addition, the study of miRNAs not only allows us to determine their importance in plasticity but also provides a technique that is now being utilized to knock down the expression of specific genes in individual brain regions of adult animals to determine their function in these long-term adaptations.

\section{CLINICAL IMPLICATIONS}

This research will undoubtedly lead to new, more targeted, treatments for memory disorders, as well as drug addiction, depression, and other psychiatric conditions. Through better understanding of the mechanisms that underlie long-term plasticity, it might be possible to either enhance or block specific aspects of a form of plasticity depending upon the condition. For example, it may be possible to reverse the chromatin modifications that occur in response to chronic exposure to drugs of abuse by modulating the transcription factors or enzymes necessary to facilitate this process. As all forms of plasticity appear to be mediated via a finite number of basic molecular processes, the large task ahead is to determine the specific molecules, changes, and circuits that are involved in the formation of normal memories, as opposed to drug addiction or depression. It is likely, therefore, that future treatments for these disorders will have to be highly targeted toward specific adaptations.

\section{DISCLOSURE}

The authors state that they have no conflicts of interest.

\section{REFERENCES}

Abarca C, Albrecht U, Spanagel R (2002). Cocaine sensitization and reward are under the influence of circadian genes and rhythm. Proc Natl Acad Sci USA 99: 9026-9030.

Abe H, Honma S, Namihira M, Masubuchi S, Ikeda M, Ebihara S et al (2001). Clock gene expressions in the suprachiasmatic nucleus and other areas of the brain during rhythm splitting in CS mice. Brain Res Mol Brain Res 87: 92-99.

Akhtar RA, Reddy AB, Maywood ES, Clayton JD, King VM, Smith AG et al (2002). Circadian cycling of the mouse liver transcriptome, as revealed by cDNA microarray, is driven by the suprachiasmatic nucleus. Curr Biol 12: 540-550.

Alarcon JM, Malleret G, Touzani K, Vronskaya S, Ishii S, Kandel ER et al (2004). Chromatin acetylation, memory, and LTP are impaired in CBP+/- mice: a model for the cognitive deficit in Rubinstein-Taybi syndrome and its amelioration. Neuron 42: 947-959.

Albensi BC, Mattson MP (2000). Evidence for the involvement of TNF and NF-kappaB in hippocampal synaptic plasticity. Synapse 35: 151-159.

Ammon S, Mayer P, Riechert U, Tischmeyer H, Hollt V (2003). Microarray analysis of genes expressed in the frontal cortex of 
rats chronically treated with morphine and after naloxone precipitated withdrawal. Brain Res Mol Brain Res 112: 113-125.

Andretic R, Chaney S, Hirsh J (1999). Requirement of circadian genes for cocaine sensitization in Drosophila. Science 285: 1066-1068.

Ang E, Chen J, Zagouras P, Magna H, Holland J, Schaeffer E et al (2001). Induction of nuclear factor-kappaB in nucleus accumbens by chronic cocaine administration. J Neurochem 79: 221-224.

Ashraf SI, Kunes S (2006). A trace of silence: memory and microRNA at the synapse. Curr Opin Neurobiol 16: 535-539.

Ashraf SI, McLoon AL, Sclarsic SM, Kunes S (2006). Synaptic protein synthesis associated with memory is regulated by the RISC pathway in Drosophila. Cell 124: 191-205.

Atkins CM, Selcher JC, Petraitis JJ, Trzaskos JM, Sweatt JD (1998). The MAPK cascade is required for mammalian associative learning. Nat Neurosci 1: 602-609.

Barco A, Alarcon JM, Kandel ER (2002). Expression of constitutively active CREB protein facilitates the late phase of long-term potentiation by enhancing synaptic capture. Cell 108: 689-703.

Barco A, Bailey CH, Kandel ER (2006). Common molecular mechanisms in explicit and implicit memory. J Neurochem 97: $1520-1533$.

Barco A, Patterson S, Alarcon JM, Gromova P, Mata-Roig M, Morozov A et al (2005). Gene expression profiling of facilitated L-LTP in VP16-CREB mice reveals that BDNF is critical for the maintenance of LTP and its synaptic capture. Neuron 48: 123-137.

Barrot M, Olivier JD, Perrotti LI, DiLeone RJ, Berton O, Eisch AJ et al (2002). CREB activity in the nucleus accumbens shell controls gating of behavioral responses to emotional stimuli. Proc Natl Acad Sci USA 99: 11435-11440.

Barrot M, Wallace DL, Bolanos CA, Graham DL, Perrotti LI, Neve RL et al (2005). Regulation of anxiety and initiation of sexual behavior by CREB in the nucleus accumbens. Proc Natl Acad Sci USA 102: 8357-8362.

Beaujean N (2002). Fundamental features of chromatin structure. Cloning Stem Cells 4: 355-361.

Berger SL (2001). An embarrassment of niches: the many covalent modifications of histones in transcriptional regulation. Oncogene 20: 3007-3013.

Berton O, McClung CA, Dileone RJ, Krishnan V, Renthal W, Russo SJ et al (2006). Essential role of BDNF in the mesolimbic dopamine pathway in social defeat stress. Science 311: 864-868.

Bito H, Deisseroth K, Tsien RW (1996). CREB phosphorylation and dephosphorylation: a $\mathrm{Ca}(2+)$ - and stimulus duration-dependent switch for hippocampal gene expression. Cell 87: 1203-1214.

Black YD, Maclaren FR, Naydenov AV, Carlezon Jr WA, Baxter MG, Konradi C (2006). Altered attention and prefrontal cortex gene expression in rats after binge-like exposure to cocaine during adolescence. J Neurosci 26: 9656-9665.

Blendy JA (2006). The role of CREB in depression and antidepressant treatment. Biol Psychiatry 59: 1144-1150.

Boivin DB (2000). Influence of sleep-wake and circadian rhythm disturbances in psychiatric disorders. J Psychiatry Neurosci 25: 446-458.

Bunney WE, Bunney BG (2000). Molecular clock genes in man and lower animals: possible implications for circadian abnormalities in depression. Neuropsychopharmacology 22: 335-345.

Carle TL, Ohnishi YN, Ohnishi YH, Alibhai IN, Wilkinson MB, Kumar A et al (2007). Absence of conserved C-terminal degron domain contributes to $\Delta$ FosB's unique stability. Eur J Neurosci 25: 3009-3019.

Carlezon Jr WA, Duman RS, Nestler EJ (2005). The many faces of CREB. Trends Neurosci 28: 436-445.

Carlezon Jr WA, Thome J, Olson VG, Lane-Ladd SB, Brodkin ES, Hiroi $N$ et al (1998). Regulation of cocaine reward by CREB. Science 282: 2272-2275.
Charriaut-Marlangue C, Otani S, Creuzet C, Ben-Ari Y, Loeb J (1991). Rapid activation of hippocampal casein kinase II during long-term potentiation. Proc Natl Acad Sci USA 88: 10232-10236.

Chaudhury D, Colwell CS (2002). Circadian modulation of learning and memory in fear-conditioned mice. Behav Brain Res 133: 95-108.

Chaudhury D, Wang LM, Colwell CS (2005). Circadian regulation of hippocampal long-term potentiation. J Biol Rhythms 20: 225-236.

Chekanova JA, Belostotsky DA (2006). MicroRNAs and messenger RNA turnover. Methods Mol Biol 342: 73-85.

Chen AC, Shirayama Y, Shin KH, Neve RL, Duman RS (2001a). Expression of the cAMP response element binding protein (CREB) in hippocampus produces an antidepressant effect. Biol Psychiatry 49: 753-762.

Chen L, Fischle W, Verdin E, Greene WC (2001b). Duration of nuclear NF-kappaB action regulated by reversible acetylation. Science 293: 1653-1657.

Chen SL, Loffler KA, Chen D, Stallcup MR, Muscat GE (2002). The coactivator-associated arginine methyltransferase is necessary for muscle differentiation: CARM1 coactivates myocyte enhancer factor-2. J Biol Chem 277: 4324-4333.

Chen WG, Chang Q, Lin Y, Meissner A, West AE, Griffith EC et al (2003). Derepression of BDNF transcription involves calcium-dependent phosphorylation of MeCP2. Science 302: 885-889.

Cheung WL, Briggs SD, Allis CD (2000). Acetylation and chromosomal functions. Curr Opin Cell Biol 12: 326-333.

Cho K, Ennaceur A, Cole JC, Suh CK (2000). Chronic jet lag produces cognitive deficits. J Neurosci 20: RC66.

Choi KH, Whisler K, Graham DL, Self DW (2006). Antisenseinduced reduction in nucleus accumbens cyclic AMP response element binding protein attenuates cocaine reinforcement. Neuroscience 137: 373-383.

Colby CR, Whisler K, Steffen C, Nestler EJ, Self DW (2003). Striatal cell type-specific overexpression of DeltaFosB enhances incentive for cocaine. J Neurosci 23: 2488-2493.

Cole RL, Konradi C, Douglass J, Hyman SE (1995). Neuronal adaptation to amphetamine and dopamine: molecular mechanisms of prodynorphin gene regulation in rat striatum. Neuron 14: $813-823$

Collins AL, Levenson JM, Vilaythong AP, Richman R, Armstrong DL, Noebels JL et al (2004). Mild overexpression of MeCP2 causes a progressive neurological disorder in mice. Hum $\mathrm{Mol}$ Genet 13: 2679-2689.

Crosio C, Heitz E, Allis CD, Borrelli E, Sassone-Corsi P (2003). Chromatin remodeling and neuronal response: multiple signaling pathways induce specific histone $\mathrm{H} 3$ modifications and early gene expression in hippocampal neurons. J Cell Sci 116: 4905-4914.

Davie JR, Murphy LC (1990). Level of ubiquitinated histone H2B in chromatin is coupled to ongoing transcription. Biochemistry 29: $4752-4757$.

Davis HP, Squire LR (1984). Protein synthesis and memory: a review. Psychol Bull 96: 518-559.

Debruyne JP, Noton E, Lambert CM, Maywood ES, Weaver DR, Reppert SM (2006). A clock shock: mouse CLOCK is not required for circadian oscillator function. Neuron 50: 465-477.

Deisseroth K, Tsien RW (2002). Dynamic multiphosphorylation passwords for activity-dependent gene expression. Neuron 34: $179-182$.

Devan BD, Goad EH, Petri HL, Antoniadis EA, Hong NS, Ko CH et al (2001). Circadian phase-shifted rats show normal acquisition but impaired long-term retention of place information in the water task. Neurobiol Learn Mem 75: 51-62.

Doi M, Hirayama J, Sassone-Corsi P (2006). Circadian regulator CLOCK is a histone acetyltransferase. Cell 125: 497-508. 
Dong Y, Green T, Saal D, Marie H, Neve R, Nestler EJ et al (2006). CREB modulates excitability of nucleus accumbens neurons. Nat Neurosci 9: 475-477.

Dubnau J, Chiang AS, Grady L, Barditch J, Gossweiler S, McNeil J et al (2003). The staufen/pumilio pathway is involved in Drosophila long-term memory. Curr Biol 13: 286-296.

Duffield GE, Best JD, Meurers BH, Bittner A, Loros JJ, Dunlap JC (2002). Circadian programs of transcriptional activation, signaling, and protein turnover revealed by microarray analysis of mammalian cells. Curr Biol 12: 551-557.

Duman RS (2002). Pathophysiology of depression: the concept of synaptic plasticity. Eur Psychiatry 17(Suppl 3): 306-310.

Easton A, Arbuzova J, Turek FW (2003). The circadian Clock mutation increases exploratory activity and escape-seeking behavior. Genes Brain Behav 2: 11-19.

Ehlers MD (2003). Activity level controls postsynaptic composition and signaling via the ubiquitin-proteasome system. Nat Neurosci 6: $231-242$.

Fernandez RI, Lyons LC, Levenson J, Khabour O, Eskin A (2003). Circadian modulation of long-term sensitization in Aplysia. Proc Natl Acad Sci USA 100: 14415-14420.

Fonseca R, Nagerl UV, Bonhoeffer T (2006). Neuronal activity determines the protein synthesis dependence of long-term potentiation. Nat Neurosci 9: 478-480.

Georgescu D, Sears RM, Hommel JD, Barrot M, Bolanos CA, Marsh DJ et al (2005). The hypothalamic neuropeptide melaninconcentrating hormone acts in the nucleus accumbens to modulate feeding behavior and forced-swim performance. J Neurosci 25: 2933-2940.

Georgescu D, Zachariou V, Barrot M, Mieda M, Willie JT, Eisch AJ et al (2003). Involvement of the lateral hypothalamic peptide orexin in morphine dependence and withdrawal. J Neurosci 23: 3106-3111.

Granados-Fuentes D, Tseng A, Herzog ED (2006). A circadian clock in the olfactory bulb controls olfactory responsivity. J Neurosci 26: 12219-12225.

Grandin LD, Alloy LB, Abramson LY (2006). The social zeitgeber theory, circadian rhythms, and mood disorders: review and evaluation. Clin Psychol Rev 26: 679-694.

Green TA, Alibhai IN, Hommel JD, DiLeone RJ, Kumar A, Theobald DE et al (2006). Induction of inducible cAMP early repressor expression in nucleus accumbens by stress or amphetamine increases behavioral responses to emotional stimuli. J Neurosci 26: 8235-8242.

Gronli J, Bramham C, Murison R, Kanhema T, Fiske E, Bjorvatn B et al (2006). Chronic mild stress inhibits BDNF protein expression and CREB activation in the dentate gyrus but not in the hippocampus proper. Pharmacol Biochem Behav 85: 842-849.

Guan Z, Giustetto M, Lomvardas S, Kim JH, Miniaci MC, Schwartz $\mathrm{JH}$ et al (2002). Integration of long-term-memory-related synaptic plasticity involves bidirectional regulation of gene expression and chromatin structure. Cell 111: 483-493.

Guillaumond F, Dardente $\mathrm{H}$, Giguere V, Cermakian $\mathrm{N}$ (2005). Differential control of Bmall circadian transcription by REV-ERB and ROR nuclear receptors. J Biol Rhythms 20: 391-403.

Hansen TO, Rehfeld JF, Nielsen FC (2004). GSK-3beta reduces cAMP-induced cholecystokinin gene expression by inhibiting CREB binding. Neuroreport 15: 841-845.

Harms E, Young MW, Saez L (2003). CK1 and GSK3 in the Drosophila and mammalian circadian clock. Novartis Found Symp 253: 267-277. discussion 102-269, 277-284.

Hess J, Angel P, Schorpp-Kistner M (2004). AP-1 subunits: quarrel and harmony among siblings. J Cell Sci 117: 5965-5973.

Hooper C, Markevich V, Plattner F, Killick R, Schofield E, Engel T et al (2007). Glycogen synthase kinase-3 inhibition is integral to long-term potentiation. Eur J Neurosci 25: 81-86.
Hotte M, Thuault S, Dineley KT, Hemmings Jr HC, Nairn AC, Jay TM (2007). Phosphorylation of CREB and DARPP-32 during late LTP at hippocampal to prefrontal cortex synapses in vivo. Synapse 61: 24-28.

Huang YS, Jung MY, Sarkissian M, Richter JD (2002). N-methyl-Daspartate receptor signaling results in Aurora kinase-catalyzed CPEB phosphorylation and alpha CaMKII mRNA polyadenylation at synapses. EMBO J 21: 2139-2148.

Huletsky A, Niedergang C, Frechette A, Aubin R, Gaudreau A, Poirier GG (1985). Sequential ADP-ribosylation pattern of nucleosomal histones. ADP-ribosylation of nucleosomal histones. Eur J Biochem 146: 277-285.

Hyman SE, Cole RL, Konradi C, Kosofsky BE (1995). Dopamine regulation of transcription factor-target interactions in rat striatum. Chem Senses 20: 257-260.

Hyman SE, Malenka RC, Nestler EJ (2006). Neural mechanisms of addiction: the role of reward-related learning and memory. Annu Rev Neurosci 29: 565-598.

Iijima M, Nikaido T, Akiyama M, Moriya T, Shibata S (2002). Methamphetamine-induced, suprachiasmatic nucleus-independent circadian rhythms of activity and mPer gene expression in the striatum of the mouse. Eur J Neurosci 16: 921-929.

Iitaka C, Miyazaki K, Akaike T, Ishida N (2005). A role for glycogen synthase kinase-3beta in the mammalian circadian clock. J Biol Chem 280: 29397-29402.

Jasnow AM, Shi C, Israel JE, Davis M, Huhman KL (2005). Memory of social defeat is facilitated by cAMP response element-binding protein overexpression in the amygdala. Behav Neurosci 119: $1125-1130$

Johannessen M, Delghandi MP, Moens U (2004). What turns CREB on? Cell Signal 16: 1211-1227.

Jope RS, Roh MS (2006). Glycogen synthase kinase-3 (GSK3) in psychiatric diseases and therapeutic interventions. Curr Drug Targets 7: 1421-1434.

Josselyn SA, Kida S, Silva AJ (2004). Inducible repression of CREB function disrupts amygdala-dependent memory. Neurobiol Learn Mem 82: 159-163.

Josselyn SA, Shi C, Carlezon Jr WA, Neve RL, Nestler EJ, Davis M (2001). Long-term memory is facilitated by cAMP response element-binding protein overexpression in the amygdala. $J$ Neurosci 21: 2404-2412.

Kaltschmidt B, Ndiaye D, Korte M, Pothion S, Arbibe L, Prullage M et al (2006). NF-kappaB regulates spatial memory formation and synaptic plasticity through protein kinase A/CREB signaling. Mol Cell Biol 26: 2936-2946.

Kaltschmidt B, Widera D, Kaltschmidt C (2005). Signaling via NF-kappaB in the nervous system. Biochim Biophys Acta 1745 287-299.

Kawahara Y, Zinshteyn B, Sethupathy P, Iizasa H, Hatzigeorgiou AG, Nishikura K (2007). Redirection of silencing targets by adenosine-to-inosine editing of miRNAs. Science 315: 11371140 .

Kelz MB, Chen J, Carlezon Jr WA, Whisler K, Gilden L, Beckmann AM et al (1999). Expression of the transcription factor deltaFosB in the brain controls sensitivity to cocaine. Nature 401: 272-276.

King DP, Takahashi JS (2000). Molecular genetics of circadian rhythms in mammals. Annu Rev Neurosci 23: 713-742.

King DP, Zhao Y, Sangoram AM, Wilsbacher LD, Tanaka M, Antoch MP et al (1997). Positional cloning of the mouse circadian clock gene. Cell 89: 641-653.

Klugmann M, Leichtlein CB, Symes CW, Klaussner BC, Brooks AI, Young D et al (2006). A novel role of circadian transcription factor DBP in hippocampal plasticity. Mol Cell Neurosci 31: 303-314.

Knippschild U, Gocht A, Wolff S, Huber N, Lohler J, Stoter M (2005). The casein kinase 1 family: participation in multiple cellular processes in eukaryotes. Cell Signal 17: 675-689. 
Konradi C, Cole RL, Heckers S, Hyman SE (1994). Amphetamine regulates gene expression in rat striatum via transcription factor CREB. J Neurosci 14: 5623-5634.

Korzus E, Rosenfeld MG, Mayford M (2004). CBP histone acetyltransferase activity is a critical component of memory consolidation. Neuron 42: 961-972.

Krug M, Lossner B, Ott T (1984). Anisomycin blocks the late phase of long-term potentiation in the dentate gyrus of freely moving rats. Brain Res Bull 13: 39-42.

Kumar A, Choi KH, Renthal W, Tsankova NM, Theobald DE, Truong HT et al (2005). Chromatin remodeling is a key mechanism underlying cocaine-induced plasticity in striatum. Neuron 48: 303-314.

Kurabayashi N, Hirota T, Harada Y, Sakai M, Fukada Y (2006). Phosphorylation of mCRY2 at Ser557 in the hypothalamic suprachiasmatic nucleus of the mouse. Chronobiol Int 23: 129-134.

Lenox RH, Gould TD, Manji HK (2002). Endophenotypes in bipolar disorder. Am J Med Genet 114: 391-406.

Levenson JM, O'Riordan KJ, Brown KD, Trinh MA, Molfese DL, Sweatt JD (2004). Regulation of histone acetylation during memory formation in the hippocampus. J Biol Chem 279: 4054540559.

Levenson JM, Roth TL, Lubin FD, Miller CA, Huang IC, Desai P et al (2006). Evidence that DNA (cytosine-5) methyltransferase regulates synaptic plasticity in the hippocampus. J Biol Chem 281: 15763-15773.

Levine AA, Guan Z, Barco A, Xu S, Kandel ER, Schwartz JH (2005). CREB-binding protein controls response to cocaine by acetylating histones at the fosB promoter in the mouse striatum. Proc Natl Acad Sci USA 102: 19186-19191.

Liu Y, Wang Y, Wan C, Zhou W, Peng T, Wang Z et al (2005). The role of mPerl in morphine dependence in mice. Neuroscience 130: $383-388$

Lonze BE, Ginty DD (2002). Function and regulation of CREB family transcription factors in the nervous system. Neuron 35: 605-623.

Lukiw WJ (2007). Micro-RNA speciation in fetal, adult and Alzheimer's disease hippocampus. Neuroreport 18: 297-300.

Lyons LC, Collado MS, Khabour O, Green CL, Eskin A (2006). The circadian clock modulates core steps in long-term memory formation in Aplysia. J Neurosci 26: 8662-8671.

Lyons LC, Rawashdeh O, Katzoff A, Susswein AJ, Eskin A (2005). Circadian modulation of complex learning in diurnal and nocturnal Aplysia. Proc Natl Acad Sci USA 102: 12589-12594.

Mahadevan LC, Willis AC, Barratt MJ (1991). Rapid histone H3 phosphorylation in response to growth factors, phorbol esters, okadaic acid, and protein synthesis inhibitors. Cell 65: 775-783.

Malenka RC, Bear MF (2004). LTP and LTD: an embarrassment of riches. Neuron 44: 5-21.

Manev $\mathrm{H}, \mathrm{Uz} \mathrm{T}$ (2006). Clock genes: influencing and being influenced by psychoactive drugs. Trends Pharmacol Sci 27: 186-189.

Mansour HA, Monk TH, Nimgaonkar VL (2005). Circadian genes and bipolar disorder. Ann Med 37: 196-205.

Marie H, Morishita W, Yu X, Calakos N, Malenka RC (2005). Generation of silent synapses by acute in vivo expression of CaMKIV and CREB. Neuron 45: 741-752.

Martinowich K, Hattori D, Wu H, Fouse S, He F, Hu Y et al (2003). DNA methylation-related chromatin remodeling in activitydependent BDNF gene regulation. Science 302: 890-893.

Mattson MP (2005). NF-kappaB in the survival and plasticity of neurons. Neurochem Res 30: 883-893.

Mayford M, Kandel ER (1999). Genetic approaches to memory storage. Trends Genet 15: 463-470.

Mayr B, Montminy M (2001). Transcriptional regulation by the phosphorylation-dependent factor CREB. Nat Rev Mol Cell Biol 2: 599-609.
McClung CA (2007). Circadian genes, rhythms and the biology of mood disorders. Pharmacol Ther 114: 222-232.

McClung CA, Nestler EJ (2003). Regulation of gene expression and cocaine reward by CREB and DeltaFosB. Nat Neurosci 6: $1208-1215$

McClung CA, Sidiropoulou K, Vitaterna M, Takahashi JS, White FJ, Cooper DC et al (2005). Regulation of dopaminergic transmission and cocaine reward by the Clock gene. Proc Natl Acad Sci USA 102: 9377-9381.

McClung CA, Ulery PG, Perrotti LI, Zachariou V, Berton O, Nestler EJ (2004). DeltaFosB: a molecular switch for long-term adaptation in the brain. Brain Res Mol Brain Res 132: 146-154.

McDearmon EL, Patel KN, Ko CH, Walisser JA, Schook AC, Chong JL et al (2006). Dissecting the functions of the mammalian clock protein BMAL1 by tissue-specific rescue in mice. Science 314: $1304-1308$.

Mieda M, Williams SC, Richardson JA, Tanaka K, Yanagisawa M (2006). The dorsomedial hypothalamic nucleus as a putative food-entrainable circadian pacemaker. Proc Natl Acad Sci USA 103: $12150-12155$.

Miller CA, Sweatt JD (2007). Covalent modification of DNA regulates memory formation. Neuron 53: 857-869.

Miller JC, Jimenez P, Mathe AA (2006). Restraint stress influences AP-1 and CREB DNA-binding activity induced by chronic lithium treatment in the rat frontal cortex and hippocampus. Int J Neuropsychopharmacol 12: 1-11.

Mioduszewska B, Jaworski J, Kaczmarek L (2003). Inducible cAMP early repressor (ICER) in the nervous system - a transcriptional regulator of neuronal plasticity and programmed cell death. J Neurochem 87: 1313-1320.

Montarolo PG, Kandel ER, Schacher S (1988). Long-term heterosynaptic inhibition in Aplysia. Nature 333: 171-174.

Morgan HD, Santos F, Green K, Dean W, Reik W (2005). Epigenetic reprogramming in mammals. Hum Mol Genet 14(Spec No 1): R47-R58.

Mouravlev A, Dunning J, Young D, During MJ (2006). Somatic gene transfer of cAMP response element-binding protein attenuates memory impairment in aging rats. Proc Natl Acad Sci USA 103: 4705-4710.

Nathan D, Sterner DE, Berger SL (2003). Histone modifications: now summoning sumoylation. Proc Natl Acad Sci USA 100: 13118-13120.

Naylor E, Bergmann BM, Krauski K, Zee PC, Takahashi JS, Vitaterna $\mathrm{MH}$ et al (2000). The circadian clock mutation alters sleep homeostasis in the mouse. J Neurosci 20: 8138-8143.

Nelson ED, Kavalali ET, Monteggia LM (2006). MeCP2-dependent transcriptional repression regulates excitatory neurotransmission. Curr Biol 16: 710-716.

Nestler EJ (2005). Is there a common molecular pathway for addiction? Nat Neurosci 8: 1445-1449.

Nestler EJ, Carlezon Jr WA (2006). The mesolimbic dopamine reward circuit in depression. Biol Psychiatry 59: 1151-1159.

Nestler EJ, Barrot M, DiLeone RJ, Eisch AJ, Gold SJ, Monteggia LM (2002). Neurobiology of depression. Neuron 34: 13-25.

Newton SS, Thome J, Wallace TL, Shirayama Y, Schlesinger L, Sakai $\mathrm{N}$ et al (2002). Inhibition of cAMP response elementbinding protein or dynorphin in the nucleus accumbens produces an antidepressant-like effect. J Neurosci 22: 1088310890.

Nikaido T, Akiyama M, Moriya T, Shibata S (2001). Sensitized increase of period gene expression in the mouse caudate/ putamen caused by repeated injection of methamphetamine. $\mathrm{Mol}$ Pharmacol 59: 894-900.

Ogden CA, Rich ME, Schork NJ, Paulus MP, Geyer MA, Lohr JB et al (2004). Candidate genes, pathways and mechanisms for bipolar (manic-depressive) and related disorders: an expanded convergent functional genomics approach. Mol Psychiatry 9: 1007-1029. 
Olausson P, Jentsch JD, Tronson N, Neve RL, Nestler EJ, Taylor JR (2006). DeltaFosB in the nucleus accumbens regulates foodreinforced instrumental behavior and motivation. J Neurosci 26: 9196-9204.

Olson VG, Green TA, Neve RL, Nestler EJ (2007). Regulation of morphine reward and feeding by CREB in the lateral hypothalamus. Synapse 61: 110-113.

Olson VG, Zabetian CP, Bolanos CA, Edwards S, Barrot M, Eisch $\mathrm{AJ}$ et al (2005). Regulation of drug reward by cAMP response element-binding protein: evidence for two functionally distinct subregions of the ventral tegmental area. J Neurosci 25: 55535562 .

O’Riordan KJ, Huang IC, Pizzi M, Spano P, Boroni F, Egli R et al (2006). Regulation of nuclear factor kappaB in the hippocampus by group I metabotropic glutamate receptors. J Neurosci 26: 4870-4879.

Otani S, Roisin-Lallemand MP, Ben-Ari Y (1992). Enhancement of extracellular protein concentrations during long-term potentiation in the rat hippocampal slice. Neuroscience 47: 265-272.

Peakman MC, Colby C, Perrotti LI, Tekumalla P, Carle T, Ulery P et al (2003). Inducible, brain region-specific expression of a dominant negative mutant of c-Jun in transgenic mice decreases sensitivity to cocaine. Brain Res 970: 73-86.

Perrotti LI, Hadeishi Y, Ulery PG, Barrot M, Monteggia L, Duman RS et al (2004). Induction of deltaFosB in reward-related brain structures after chronic stress. J Neurosci 24: 10594-10602.

Pliakas AM, Carlson RR, Neve RL, Konradi C, Nestler EJ, Carlezon Jr WA (2001). Altered responsiveness to cocaine and increased immobility in the forced swim test associated with elevated cAMP response element-binding protein expression in nucleus accumbens. J Neurosci 21: 7397-7403.

Presutti C, Rosati J, Vincenti S, Nasi S (2006). Non coding RNA and brain. BMC Neurosci 7(Suppl 1): S5.

Prickaerts J, Moechars D, Cryns K, Lenaerts I, van Craenendonck $\mathrm{H}$, Goris I et al (2006). Transgenic mice overexpressing glycogen synthase kinase 3beta: a putative model of hyperactivity and mania. J Neurosci 26: 9022-9029.

Reick M, Garcia JA, Dudley C, McKnight SL (2001). NPAS2: an analog of clock operative in the mammalian forebrain. Science 293: 506-509.

Reppert SM, Weaver DR (2001). Molecular analysis of mammalian circadian rhythms. Annu Rev Physiol 63: 647-676.

Romano A, Freudenthal R, Merlo E, Routtenberg A (2006). Evolutionarily-conserved role of the NF-kappaB transcription factor in neural plasticity and memory. Eur J Neurosci 24: $1507-1516$

Roybal K, Theobold D, Graham A, Dinieri JA, Russo SJ, Krishnan $\mathrm{V}$ et al (2007). Mania-like behavior induced by disruption of CLOCK. Proc Natl Acad Sci USA 104: 6406-6411.

Rudy JW, Biedenkapp JC, Moineau J, Bolding K (2006). Anisomycin and the reconsolidation hypothesis. Learn Mem 13: $1-3$.

Sakai T, Tamura T, Kitamoto T, Kidokoro Y (2004). A clock gene, period, plays a key role in long-term memory formation in Drosophila. Proc Natl Acad Sci USA 101: 16058-16063.

Salas TR, Reddy SA, Clifford JL, Davis RJ, Kikuchi A, Lippman SM et al (2003). Alleviating the suppression of glycogen synthase kinase-3beta by Akt leads to the phosphorylation of cAMPresponse element-binding protein and its transactivation in intact cell nuclei. J Biol Chem 278: 41338-41346.

Sassone-Corsi P, Mizzen CA, Cheung P, Crosio C, Monaco L, Jacquot $S$ et al (1999). Requirement of Rsk-2 for epidermal growth factor-activated phosphorylation of histone H3. Science 285: 886-891.

Sato TK, Panda S, Miraglia LJ, Reyes TM, Rudic RD, McNamara P et al (2004). A functional genomics strategy reveals Rora as a component of the mammalian circadian clock. Neuron 43: 527-537.
Schafe GE, Atkins CM, Swank MW, Bauer EP, Sweatt JD, LeDoux JE (2000). Activation of ERK/MAP kinase in the amygdala is required for memory consolidation of pavlovian fear conditioning. J Neurosci 20: 8177-8187.

Schratt GM, Tuebing F, Nigh EA, Kane CG, Sabatini ME, Kiebler M et al (2006). A brain-specific microRNA regulates dendritic spine development. Nature 439: 283-289.

Schroeder FA, Lin CL, Crusio WE, Akbarian S (2006). Antidepressant-like effects of the histone deacetylase inhibitor, sodium butyrate, in the mouse. Biol Psychiatry 62: 55-64.

Shaw-Lutchman TZ, Barrot M, Wallace T, Gilden L, Zachariou V, Impey $S$ et al (2002). Regional and cellular mapping of cAMP response element-mediated transcription during naltrexoneprecipitated morphine withdrawal. J Neurosci 22: 3663-3672.

Shaw-Lutchman TZ, Impey S, Storm D, Nestler EJ (2003). Regulation of CRE-mediated transcription in mouse brain by amphetamine. Synapse 48: 10-17.

Si K, Giustetto M, Etkin A, Hsu R, Janisiewicz AM, Miniaci MC et al (2003). A neuronal isoform of CPEB regulates local protein synthesis and stabilizes synapse-specific long-term facilitation in aplysia. Cell 115: 893-904.

Spanagel R, Pendyala G, Abarca C, Zghoul T, Sanchis-Segura C, Magnone MC et al (2005). The clock gene Per2 influences the glutamatergic system and modulates alcohol consumption. Nat Med 11: 35-42.

Stanton PK, Sarvey JM (1984). Blockade of long-term potentiation in rat hippocampal CA1 region by inhibitors of protein synthesis. J Neurosci 4: 3080-3088.

Stokkan KA, Yamazaki S, Tei H, Sakaki Y, Menaker M (2001). Entrainment of the circadian clock in the liver by feeding. Science 291: 490-493.

Taubenfeld SM, Wiig KA, Bear MF, Alberini CM (1999). A molecular correlate of memory and amnesia in the hippocampus. Nat Neurosci 2: 309-310.

Tsankova NM, Berton O, Renthal W, Kumar A, Neve RL, Nestler EJ (2006). Sustained hippocampal chromatin regulation in a mouse model of depression and antidepressant action. Nat Neurosci 9: 519-525.

Tsankova NM, Kumar A, Nestler EJ (2004). Histone modifications at gene promoter regions in rat hippocampus after acute and chronic electroconvulsive seizures. J Neurosci 24: 5603-5610.

Ulery PG, Nestler EJ (2007). Regulation of DeltaFosB transcriptional activity by Ser27 phosphorylation. Eur J Neurosci 25: 224-230.

Ulery PG, Rudenko G, Nestler EJ (2006). Regulation of DeltaFosB stability by phosphorylation. J Neurosci 26: 5131-5142.

Uz T, Ahmed R, Akhisaroglu M, Kurtuncu M, Imbesi M, Dirim Arslan A et al (2005). Effect of fluoxetine and cocaine on the expression of clock genes in the mouse hippocampus and striatum. Neuroscience 134: 1309-1316.

Valentinuzzi VS, Menna-Barreto L, Xavier GF (2004). Effect of circadian phase on performance of rats in the Morris water maze task. J Biol Rhythms 19: 312-324.

Vo N, Klein ME, Varlamova O, Keller DM, Yamamoto T, Goodman $\mathrm{RH}$ et al (2005). A cAMP-response element binding proteininduced microRNA regulates neuronal morphogenesis. Proc Natl Acad Sci USA 102: 16426-16431.

Wagatsuma A, Sugai R, Chono K, Azami S, Hatakeyama D, Sadamoto $\mathrm{H}$ et al (2004). The early snail acquires the learning. Comparison of scores for conditioned taste aversion between morning and afternoon. Acta Biol Hung 55: 149-155.

Walker MP, Stickgold R (2006). Sleep, memory, and plasticity. Annu Rev Psychol 57: 139-166.

Wallace TL, Stellitano KE, Neve RL, Duman RS (2004). Effects of cyclic adenosine monophosphate response element binding protein overexpression in the basolateral amygdala on behavioral models of depression and anxiety. Biol Psychiatry 56 $151-160$. 
Walters CL, Blendy JA (2001). Different requirements for cAMP response element binding protein in positive and negative reinforcing properties of drugs of abuse. J Neurosci 21: 94389444.

Walters CL, Cleck JN, Kuo YC, Blendy JA (2005). Mu-opioid receptor and CREB activation are required for nicotine reward. Neuron 46: 933-943.

Walters CL, Kuo YC, Blendy JA (2003). Differential distribution of CREB in the mesolimbic dopamine reward pathway. I Neurochem 87: 1237-1244.

Wang LM, Suthana NA, Chaudhury D, Weaver DR, Colwell CS (2005). Melatonin inhibits hippocampal long-term potentiation. Eur J Neurosci 22: 2231-2237.

Weaver IC, Cervoni N, Champagne FA, D'Alessio AC, Sharma S, Seckl JR et al (2004). Epigenetic programming by maternal behavior. Nat Neurosci 7: 847-854.

Weaver IC, Champagne FA, Brown SE, Dymov S, Sharma S, Meaney MJ et al (2005). Reversal of maternal programming of stress responses in adult offspring through methyl supplementation: altering epigenetic marking later in life. J Neurosci 25: 11045-11054.

Werme M, Messer C, Olson L, Gilden L, Thoren P, Nestler EJ et al (2002). Delta FosB regulates wheel running. J Neurosci 22: 8133-8138.

Williams JM, Beckmann AM, Mason-Parker SE, Abraham WC, Wilce PA, Tate WP (2000). Sequential increase in Egr-1 and AP-1 DNA binding activity in the dentate gyrus following the induction of long-term potentiation. Brain Res Mol Brain Res 77: $258-266$

Williamson SL, Christodoulou J (2006). Rett syndrome: new clinical and molecular insights. Eur J Hum Genet 14: 896-903.

Wirz-Justice A (2006). Biological rhythm disturbances in mood disorders. Int Clin Psychopharmacol 21(Suppl 1): S11-S15.

Wood MA, Kaplan MP, Park A, Blanchard EJ, Oliveira AM, Lombardi TL et al (2005). Transgenic mice expressing a truncated form of CREB-binding protein (CBP) exhibit deficits in hippocampal synaptic plasticity and memory storage. Learn Mem 12: 111-119.

Wu GY, Deisseroth K, Tsien RW (2001). Activity-dependent CREB phosphorylation: convergence of a fast, sensitive calmodulin kinase pathway and a slow, less sensitive mitogen-activated protein kinase pathway. Proc Natl Acad Sci USA 98: 2808-2813.

Wu J, Xie X (2006). Comparative sequence analysis reveals an intricate network among REST, CREB and miRNA in mediating neuronal gene expression. Genome Biol 7: R85.
Wu L, Wells D, Tay J, Mendis D, Abbott MA, Barnitt A et al (1998). CPEB-mediated cytoplasmic polyadenylation and the regulation of experience-dependent translation of alpha-CaMKII mRNA at synapses. Neuron 21: 1129-1139.

Xu Y, Ku B, Tie L, Yao H, Jiang W, Ma X et al (2006). Curcumin reverses the effects of chronic stress on behavior, the HPA axis, BDNF expression and phosphorylation of CREB. Brain Res 1122: 56-64.

Yeh SH, Lin CH, Gean PW (2004). Acetylation of nuclear factorkappaB in rat amygdala improves long-term but not short-term retention of fear memory. Mol Pharmacol 65: 1286-1292.

Yeh SH, Lin CH, Lee CF, Gean PW (2002). A requirement of nuclear factor-kappaB activation in fear-potentiated startle. J Biol Chem 277: 46720-46729.

Yin JC, Tully T (1996). CREB and the formation of long-term memory. Curr Opin Neurobiol 6: 264-268.

Yin JC, Del Vecchio M, Zhou H, Tully T (1995). CREB as a memory modulator: induced expression of a dCREB2 activator isoform enhances long-term memory in Drosophila. Cell 81: 107-115.

Yuferov V, Butelman ER, Kreek MJ (2005). Biological clock: biological clocks may modulate drug addiction. Eur J Hum Genet 13: 1101-1103.

Yuferov V, Kroslak T, Laforge KS, Zhou Y, Ho A, Kreek MJ (2003). Differential gene expression in the rat caudate putamen after 'binge' cocaine administration: advantage of triplicate microarray analysis. Synapse 48: 157-169.

Zachariou V, Bolanos CA, Selley DE, Theobald D, Cassidy MP, Kelz MB et al (2006). An essential role for DeltaFosB in the nucleus accumbens in morphine action. Nat Neurosci 9: 205-211.

Zghoul T, Abarca C, Sanchis-Segura C, Albrecht U, Schumann G, Spanagel R (2007). Ethanol self-administration and reinstatement of ethanol-seeking behavior in $\operatorname{Per} 1(\mathrm{Brdm} 1)$ mutant mice. Psychopharmacology (Berlin) 190: 13-19.

Zhang H, Darwanto A, Linkhart TA, Sowers LC, Zhang L (2007). Maternal cocaine administration causes an epigenetic modification of PKC\{epsilon\} gene expression in fetal rat heart. Mol Pharmacol 71: 1319-1328.

Zhu H, Lee M, Agatsuma S, Hiroi N (2007). Pleiotropic impact of constitutive fosB inactivation on nicotine-induced behavioral alterations and stress-related traits in mice. Hum Mol Genet 16: 820-836.

Zueger M, Urani A, Chourbaji S, Zacher C, Lipp HP, Albrecht U et al (2006). mPer1 and mPer2 mutant mice show regular spatial and contextual learning in standardized tests for hippocampusdependent learning. J Neural Transm 113: 347-356. 